\title{
Perceived stress, ego-resiliency, and relational resources as predictors of psychological well-being in parents of children with Down syndrome
}

\begin{abstract}
BACKGROUND
The objective of the present study was to examine the role of perceived stress, ego-resiliency, and relational resources in maintaining psychological well-being in parents of children with Down syndrome, in particular in groups of mothers and fathers. Being a parent of a child with a disability is stressful, and it can be a burden. Despite these negative aspects of child-rearing, mothers and fathers are supported by their own resources and help from other people.
\end{abstract}

\section{PARTICIPANTS AND PROCEDURE}

The study included 126 parents of children with Down syndrome ( 75 mothers and 51 fathers). All parents were married at the time of the study (i.e. the study did not involve single parents). The subjects completed questionnaires of psychological well-being, perceived stress, ego-resiliency, quality of marital relationship, and perceived social support.

\section{RESULTS}

Perceived stress proved to be a negative predictor $(\beta=-.35)$ of psychological well-being both in the group of all parents and in groups of mothers and fathers. Ego-resiliency, perceived social support, and quality of marital relationship were positive predictors in the group of all parents, whereas ego-resiliency was a positive predictor $(\beta=.29)$ of psychological well-being of fathers; perceived social support constituted a positive predictor $(\beta=.25)$ in the group of mothers.

\section{CONCLUSIONS}

The results of the present study show the factors that have a significant effect on parental well-being and may, thus, be unfavourable (e.g. perceived stress) or favourable (e.g. perceived social support for mothers, ego-resiliency for fathers) for adaptation of parents of children with Down syndrome and their mental health. Particularly interesting are the differences in groups of mothers and fathers with regard to factors positively affecting their psychological well-being: relational resources (social support) are factors important for mothers, whereas psychological inner resources (ego-resiliency) are important for fathers. Further research on the topic is needed.

KEY WORDS

social support; well-being; Down syndrome; parental stress; ego-resiliency 


\section{BACKGROUND}

A child with Down syndrome in the family can affect it at different levels, from the micro-level of mutual interactions to the macro-level of social and cultural opinions affecting parental perceptions about the child's disability (Cuskelly, Hauser-Cram, \& Van Riper, 2009). Parents encounter specific, difficult daily stressors associated with their child's disability. Down syndrome is a chromosome mutation affecting both physical and intellectual capabilities: the rate of appearance of the syndrome is 1 in 800 births (Mikyong et al., 2009). About 25 to 33 per cent of families with a Down syndrome child experience difficulties: this results in higher levels of measured distress and poorer satisfaction with life (Cunningham, 1996). Increased symptoms of depression were found among parents of children with chronic medical conditions (cf. Barnett, Clements, Kaplan-Estrin, \& Fialka, 2003). Undoubtedly, being exposed to stress can be regarded as a potential risk factor for the process of parental adaptation and family functioning (Kandel \& Merrick, 2003; Hedov, Anneren, \& Wikblad, 2002).

There are many sources of stress for parents of children with Down syndrome. This kind of stress may be linked to various non-specific conditions and challenges that emerge when parents are taking care of a mentally disabled child with many limitations and little hope for improvement (Pisula, 2007a); it can become a burden and may negatively affect the physical and psychological health of both mother and father (Malhotra, Khan, \& Bhatia, 2012).

Apart from fears concerning children's everyday medical and social situation, parents are also worried about their difficult-to-predict future. Effects of parental stress can be noticed in the parents' relationships with family, friends, and neighbours (Kulik \& Otrębski, 2011). For example, families with children who require special care are likely to experience more marital conflicts and are unable to benefit from social support and help from family members and friends (c.f. Barnett et al., 2003). Hence, many studies on parents' adaptation to a child with Down syndrome focus predominantly on stress (e.g. Cuskelly, Hauser-Cram, \& Van Riper, 2009).

Mothers of children with disabilities, and less frequently fathers, were examined for high levels of depression and marital instability (Hodapp, 2007). It has been observed that the way a child with Down syndrome affects mothers and fathers is somewhat different. Fathers of mentally disabled children reported lower satisfaction with life over the years (Cunningham, 1996); mothers were taking on the exhausting duty of everyday care, whereas fathers struggled with family finances and future planning (Sanders \& Morgan, 1997). Fathers also showed concern that their children would be socially less acceptable due to the physical and behavioural characteristics associated with Down syndrome (Keller \& Honig, 2004).

A legitimate question arises about the effects that having a child with Down syndrome has on a family (Cunningham, 1996). Some researchers confirm the negative influence on the family (Neely-Barnes \& Dia, 2008), whereas other authors report opposite findings. No consistent answer to this question has been offered yet (Van Riper, 1999). For over three decades there has been a persisting view that a child with an intellectual or developmental disability creates problems for the family, including added stress and parental depression (Neely-Barnes \& Dia, 2008). Consequently, it was tacitly assumed that suffering was an inherent consequence of having a child with a disability. Hence, research has primarily focused on the negative effects of the child on the family (Cunningham, 1996).

The way of functioning of most families of children with disabilities is not poorer than that of other families (Lustig, 1997; see Neely-Barnes \& Dia, 2008). This observation was confirmed by other researchers (e.g. Ylvén, Björck-Åkesson, \& Granlund, 2006), who noticed positive functioning of families in stressful circumstances caused by having children with disabilities. Children with Down syndrome show many individual differences in their cognitive, social and physical abilities, health status, and personality traits (Cunningham, 1996). Firstly, there are differences between children; secondly, the parents' positive perception of the child with a disability can play a pivotal role (Neely-Barnes \& Dia, 2008). Qualitative research on the perception of parental roles conducted by the authors of the present study showed that mothers and fathers of children with Down syndrome understand their parenthood in different categories. According to these findings, parents perceive their parenthood as a burden (e.g. parents focus on the difficulties and fears connected with caring for children with Down syndrome), a challenge (e.g. parents understand their parenthood as a task to perform or life lesson), ordinariness (e.g. parents describe their parenthood as everyday life and normality), and satisfaction-happiness (e.g. parents say that their parenthood is a source of pleasant feelings and experiences for them) (Przybyła-Basista \& Kózka, 2016).

Apart from the obvious burden, parents of children with disabilities may also experience positive effects such as openness to challenges, overcoming their own psychological barriers, and personal growth. Those parents report high satisfaction and enjoyment of their role (Barnett et al., 2003). They are often ready to reformulate their dreams and plans, modify family priorities, and become more aware of their values (King et al., 2005; Barnett et al., 2003). Often, their disabled children show positive personal traits (Ricci \& Hodapp, 2003) and have an influence on their parents' positive adaptation to their situa-
Perceived stress, ego-resiliency, and relational resources 
Anna Kózka,

Hanna

Przybyła-Basista tion (King et al., 2005). Bower, Chant, and Chatwin (1998) claim that disability of a family member not only activates resilience processes, but also makes the family emotionally stronger and more resilient.

In spite of numerous difficulties, mothers of children with Down syndrome frequently report positive aspects of their situation (Joosa \& Berthelsen, 2006). They mention better mental and physical health as a result of having a child with Down syndrome (Greenberg, Mailick Seltzer, Wyngaarden, Chou, \& Hong, 2004). Van Riper (2007) reported that many families taking care of children with Down syndrome are able to cope well in spite of many challenges and misfortunes. This fact can be connected also with another protective factor - parental satisfaction involving gratification and reinforcement from being a parent. Parental satisfaction is increased by feelings of being loved and appreciated by one's child and by having a close relationship with the child (Hodapp, Ly, Fidler, \& Ricci, 2001). Laws and Millward (2001) indicate that parents of children with Down syndrome gain satisfaction from their own parental effectiveness and involvement in child's education. Many researchers notice that parents of children with Down syndrome experience lower levels of stress than parents of children with different disabilities, such as autism or cerebral palsy (Fidler, Hodapp, \& Dykens, 2000; Pisula, 2007b; Richman, Belmont, Myungjin, Slavin, \& Hayner, 2009).

Although the majority of parents notice changes in their marital functioning due to their child's disability, only $10 \%$ of them declared that these changes had a negative effect (Liberska \& Rzepa, 2011). Mothers of children with Down syndrome gain a lot of support from their spouses and describe them as very helpful (Garcia-Tunon, 1997). When mothers notice that their husbands or partners participate in caring for their disabled child, the quality of marriage tends to improve (Hallberg, 2014). It is worth noting that marital relationship quality is related to parental well-being (Kersh, Hedvat, Hauser-Cram, \& Warfield, 2006).

Baucom, Shoham, Mueser, Daiuto, and Sticker (1998) indicate that there is a need for further research on the marital relationship and the psychological well-being of parents in families of children with disabilities, not only because of the deficit of such studies, but also by virtue of the importance of this relationship in creating and maintaining proper relationships between members of these families. Hartley, Mailick Seltzer, Head, and Abbeduto (2012) suggest that research related to psychological well-being, as well as examining depressive symptoms, pessimism, and coping styles, should also study marital satisfaction in a broader perspective.

When a child with disability is born, it is not only the marital relationship that is changing. The new situation implies changes in both quantitative and qualitative aspects of the parents' social contact
(Liberska \& Rzepa, 2011). Pisula (2007a) indicates that what parents of children with Down syndrome appreciate the most are, besides financial resources, help from their family members, specialists, and other parents of children with disabilities. As a coping strategy, mothers of children with Down syndrome most frequently seek social support (Lam \& Mackenzie, 2002). On the other hand, fathers participate in group social support forms to a lower degree than mothers (West, 1998); they prefer when support is designed both for them and their wives (Turbiville \& Marquis, 2001). In comparison with fathers, mothers tend to declare the need for social and familial support more often, especially in such aspects as help with taking care of the child (Bailey, Blasco, \& Simeonsson, 1992).

The influence of stress on parents' well-being is lower when parents have such resources like social support (Kózka \& Przybyła-Basista, 2016b; Suarez \& Baker, 1997). A strong social network gives parents a chance to divide the responsibilities and worries among other people like friends, family members, and neighbours, and to gain emotional support. In this way, the stress within the marital relationship can be reduced (Marchal et al., 2013). Also, programmes designed for families with disabled children can be a source of knowledge and positive changes in such aspects as developing plans for the family and participating in various organisations (Schuh, Hagner, Villon, \& Dixon, 2015).

Functioning of parents can be considered from various perspectives: individual, family, and social. A good emotional relationship between the mother and the father is a form of protection from stress connected with the child's developmental disorders (Pisula, 2007a). Marital quality of couples raising children with Down syndrome is positively correlated with their life satisfaction (Bobkowicz-Lewartowska, 2013; Marchal, Maurice-Stam, Hatzmann, von Trotsenburg, \& Grootenhuis, 2013). Results of studies indicate that it is less likely for these parents to divorce than it is for the parents of children with other types of disabilities: in this group, divorces occurred more often before the child with Down syndrome's second birthday (Urbano \& Hodapp, 2007). What is more, Cunningham (1996) indicates that these parents get divorced less frequently than the general population.

A survey of available research results shows that individual, relational, and social resources play a key role in the process of adaptation of parents to changes caused by raising a child with Down syndrome. Cunningham (1996) presented an interesting classification of resources that can be helpful for parents: the classification comprises resources of (1) physical (e.g. health, energy, stamina), (2) utilitarian (e.g. finance, employment), (3) social (e.g. social networks, support systems), and (4) psychological (e.g. belief systems, problem solving skills, personality) nature. 
Availability of resources, their usage, and parental coping strategies can be useful in modifying the negative effect of stressful factors. If the respective resources are missing, the strain and stress on the condition of the family is likely to increase (Cunningham, 1996; Dąbrowska, 2010).

Among psychological resources, ego-resiliency is worth emphasising. The findings of the present study show that stress perceived by parents affects their well-being to a lesser degree when they own such resources as ego-resiliency (Kózka \& Przybyła-Basista, 2016a). In literature, resilience is understood as a complex phenomenon: it is sometimes defined as the individual ability to resist and face stressful experiences (Bonanno; see Dolińska-Zygmunt \& Włodarczyk, 2011), or as "a human ability to adapt in the face of tragedy, trauma, adversity, and ongoing life stressors" (Newman; see Dolińska-Zygmunt \& Włodarczyk, 2011).

Resilience is interrelated with coping and adaptation. Adaptation is understood as a process through which each person's potentialities develop as answers to environmental challenges and opportunities (Maluccio, 2002; see Dolińska-Zygmunt \& Włodarczyk, 2011). The concept of ego-resiliency (Block \& Kremen, 1996) is directly connected with resiliency, and is defined as an inner mental structure that helps people to adjust to the world through a their ability to be flexible, use personal resources and cope, develop strategies of coping with stress; it enables people to modify their experience and adjust to the demands of the world. Individuals displaying ego-resiliency can be described as flexible in acting, adjusting to changes, setting both short- and longterm goals, with a positive attitude to life (cf. Dolin'ska-Zygmunt \& Włodarczyk, 2011). As a personality construct, ego-resiliency can be quite useful when characterising parents of disabled children.

Reviewing the previous literature, one can conclude that in the process of parental adaptation, of which the psychological well-being of parents of children with Down syndrome is an essential factor, stress is the basic risk factor. Moreover, in recent papers on parental adaptation to child disability, different resources are often underlined as potential facilitators of the adaptation process and in reaching the psychological well-being. The present study focuses on three resources: ego-resiliency as an individual resource of each parent, and on two types of relational resources: perceived social support and quality of marital relationship. Empirical research results reported so far address the necessity of investigating differences between mothers and fathers in shaping the psychological well-being and the development of the adaptation process.

The primary objective of this exploratory study was to answer the following research questions:

1. Is there any difference in psychological well-being between mothers and fathers of children with
Down syndrome?

2. Which of the assumed variables (perceived stress, ego-resiliency, marital quality, perceived social support) has a significant effect on the psychological well-being of parents of children with Down syndrome?

2a. Which of the assumed variables (perceived stress, ego-resiliency, marital quality, perceived social support) has a significant effect on the psychological well-being of mothers of children with Down syndrome?

$2 \mathrm{~b}$. Which of the assumed variables (perceived stress, ego-resiliency, marital quality, perceived social support) has a significant effect on the psychological well-being of fathers of children with Down syndrome?

\section{PARTICIPANTS AND PROCEDURE}

The sample consisted of 126 parents: 75 mothers $(59.52 \%)$ and 51 fathers (40.48\%). All parents were married (i.e. there were not any single parents found in this study). The average length of marital relationship was 20.50 years $(\min 5.00, \max 48.00)$. The average age of parents was 46.54 years $(\min 25.00, \max$ 69.00); the average age of mothers was 45.33 years ( $\min 25.00, \max 69.00)$ and of fathers 48.31 years ( $\min$ 26.00, $\max 69.00)$.

The age of children with Down syndrome ranged from 1 to 39 years, with an average age of 13.25, and the children's gender was female $(51.59 \%)$ and male $(48.41 \%)$. $32.54 \%$ of children were born as the first child in the family, $43.65 \%$ as the second, and $23.81 \%$ as the third or further child. Parents described their children as nice to other people $(67.46 \%)$ and obedient (50.79\%). Approximately one third (31.74\%) of children had health problems, and $68.25 \%$ of them were not self-reliant.

The majority of parents had higher $(47.72 \%$ of mothers and $36.73 \%$ of fathers) or secondary education (38.89\% of mothers and $32.65 \%$ of fathers). Other parents had vocational education (13.89\% of mothers and $28.57 \%$ of fathers). Only one father had elementary education. Almost half of the parents lived in big and medium cities (47.75\%), one third of them lived in small towns (33.91\%), and the other parents lived in the country $(18.26 \%)$. Parents described their financial situation as: sufficient (46.72\%), good $(40.98 \%)$, very good (3.28\%), insufficient (7.38\%), and very bad (1.64\%).

More than two thirds of the fathers $(70.21 \%)$ and almost one third of the mothers (30.67\%) worked full-time. The occupational situation of parents was as follows: $12.00 \%$ of mothers and $10.64 \%$ of fathers did not work; $8.00 \%$ of mothers and $19.15 \%$ of fathers were retired; $9.33 \%$ of mothers had part-time jobs and $32.00 \%$ of them had not worked since the child with Down syndrome was born to them.
Perceived stress, ego-resiliency, and relational resources 
Anna Kózka,

Hanna

Przybyła-Basista
Parents were the residents of a few Polish voivodeships (Silesia, Masovia, Lesser Poland, Opole, West Pomerania). Each parent received a set of questionnaires in a separate envelope; they were informed about the aim of the study and asked to complete the questionnaires anonymously. The subjects were informed about the goal of the study. Participation in the survey was voluntary, and parents gave informed consent to the participation in the research. The research was conducted both by means of individual contacts with parents and with help of school headmasters, a rehabilitation centre and the chairmen of Polish associations of families and friends of children with Down syndrome.

\section{MEASURES}

Perceived stress. The level of parents' perceived stress was evaluated using the 10-item Perceived Stress Scale (PSS-10) developed by Cohen, Kamarck, and Mermelstein (1983); a Polish adaptation was created by Juczyński and Ogińska-Bulik (2009). PSS-10 focuses on symptoms of negative stress experienced in the last month. Each item has a five-point response scale from 0 (never) to 4 (very often). The PSS-10 scores are obtained by reversing the scores on the four positive questions and then summation of all 10 scores. Then, the total score is the measure of chronic stress. Example items include "In the last month, how often have you felt difficulties were piling up so high that you could not overcome them?" Cronbach's $\alpha$ coefficient for this scale was .86 .

Ego-resiliency. The level of ego-resiliency was measured with the Ego-Resiliency Scale developed by Block and Kremen (1996) and adapted by Kołodziej and Przybyła-Basista (2012). This scale consists of 12 items including such statements as: "I am considered a very energetic person" and "I am more investigative than most people". The respondents rated their level of agreement for each item on a four-grade scale, where 4 denotes - "I agree very strongly" and 1 denotes "I do not agree at all". The scale structure consists of two factors: optimal regulation (OR) and openness to new life experiences (OL). Cronbach's $\alpha$ for the Polish version of the total scale was .80, for the OR scale $=.77$, and for the OL scale $=.59$.

Marital quality. The Dyadic Adjustment Scale (DAS) by Spanier (1976) and its Polish adaptation by Cieślak (1989) assessed the quality of the marital relationship. The DAS is an item instrument that asks about the quality of the relationship, shared activities, and the extent of agreement between partners on a range of issues, including household tasks, decision making, and recreation. It is completed independently by both partners. The total score was used for analyses; Cronbach's $\alpha$ for the Polish version of this scale is .89 .
Perceived Social Support. This variable was measured by the Multidimensional Scale of Perceived Social Support (Zimet, Dahlem, Zimet, \& Harley, 1988; Polish adaptation: Buszman \& Przybyła-Basista, 2015). The scale consists of 12 items addressing relationships with significant person, family, and friends. The scale gives a general score as well as scores in three subscales: Family (i.e. "I can talk about my problems with my family"), friends (i.e. "I can count on my friends when things go wrong"), and significant other (i.e. "There is a special person in my life who cares about my feelings"). Each item is rated on a seven-point scale ranging from 1 ("strongly disagree") to 7 ("strongly agree"). The scale has good psychometric properties. Cronbach's $\alpha$ is .89 for the general score and ranges from .93 to .87 for subscales (Family - .92, Friends - .93, significant other -.87$)$.

Psychological well-being. To measure parents' psychological well-being, the Oxford Happiness Questionnaire $(\mathrm{OHQ})$ was used. The original version of this questionnaire was developed by Hills and Argyle (2002); a Polish adaptation was done by Kołodziej and Przybyła-Basista (2013). Example items include "I do not think that the world is a good place", "I always have a cheerful effect on others". The respondents rated their level of agreement for each item on a sixgrade scale with responses ranging from 6 (I absolutely agree) to 1 (I absolutely disagree). The Cronbach's $\alpha$ reliability coefficient for the Polish version of $\mathrm{OHQ}$ was .90.

Statistical analysis (descriptive, comparison, and regression analysis) was performed using the Statistica 10.0 suite (StatSoft, 2006).

\section{RESULTS}

\section{PSYCHOLOGICAL WELL-BEING OF CHILDREN WITH DOWN SYNDROME: A COMPARISON BETWEEN MOTHERS AND FATHERS}

The first objective of this study was to probe into the question of whether there is any difference in the level of psychological well-being between mothers and fathers of children with Down syndrome. The results obtained with the use of Mann-Whitney $U$ test showed that there is no significant difference in psychological well-being between the two groups $(p=.094)$. The results of this analysis are shown in Table 1.

\section{PREDICTORS OF PSYCHOLOGICAL WELL-BEING OF THE PARENTS OF CHILDREN WITH DOWN SYNDROME}

Stepwise regression (forward selection model) was used to determine which of the four factors (per- 
Table 1

A comparison of psychological well-being between mothers and fathers of children with Down syndrome (results of the Mann-Whitney $U$ test)

\begin{tabular}{lcccc}
\hline Variable & Group & $n$ & Mean rank & Sum of ranks \\
\hline Psychological & Mothers & 75 & 59.00 & 4425.00 \\
well-being & Fathers & 51 & 71.12 & 3576.00 \\
\hline
\end{tabular}

Test statistics: $U=1575.00 ; Z=-1.67 ; p=.094$.

ceived stress, ego-resiliency, marital quality, perceived social support) are predictors of psychological well-being among parents of children with Down syndrome. The statistical significance of the assumed model was confirmed by the results of regression analyses. The independent variables of the model explained approximately $50 \%$ of the total variance of the dependent variable. For the group of all parents $(n=126)$, perceived stress was the most significant predictor of psychological well-being $(\beta=-.35$, $p<.001)$. Other significant predictors were: perceived social support $(\beta=.21, p=.007)$, ego-resiliency $(\beta=.21, p=.004)$, and marital quality $(\beta=.18$, $p=.035)$. The results are shown in Table 2 .

\section{PREDICTORS OF PSYCHOLOGICAL WELL-BEING OF MOTHERS OF CHILDREN WITH DOWN SYNDROME}

The variables defined above were used to recognise the predictors of psychological well-being also in the group of mothers of children with Down syndrome $(n=75)$. Here, perceived stress was again the strongest predictor $(\beta=-.34, p=.004)$. Perceived social support $(\beta=.25, p=.024)$ was the second significant predictor; the other variables turned out to be statistically insignificant. The results of the analysis for this group are presented in Table 3.

\section{PREDICTORS OF PSYCHOLOGICAL WELL-BEING OF FATHERS OF CHILDREN WITH DOWN SYNDROME}

The results of the analysis in the group of fathers are shown in Table 4 . The strongest predictor was perceived stress $(\beta=-.38, p=.003)$; the second significant predictor was ego-resiliency $(\beta=.29$, $p=.012$ ). The other variables (perceived social support and marital quality) turned out to be statistically insignificant.

To conclude, the regression analysis in the whole group of parents showed the most significant predictor of their psychological well-being to be the perceived stress. The other predictors were: perceived social support, ego-resiliency, and marital quality.
In groups of mothers and fathers separately, perceived stress also turned out to be the most significant predictor of psychological well-being. The other significant predictors were: perceived social support in the group of mothers and ego-resiliency in the group of fathers. Another variable - marital quality - was not proven to be a predictor of either mothers' or fathers' psychological well-being.

Table 2

Predictors of psychological well-being of the parents of children with Down syndrome for the total group of parents $(n=126)$

\begin{tabular}{lccc}
\hline Variable & $\beta$ & $t$ & $p$ \\
\hline Perceived stress & -.35 & -4.36 & .001 \\
Perceived social support & .21 & 2.73 & .007 \\
Ego-resiliency & .21 & 2.97 & .004 \\
Marital quality & .18 & 2.14 & .035 \\
\hline Statistics of the model: $R^{2}=.50 ; F=32.727 ; d f=4 ; p<.001$.
\end{tabular}

Table 3

Predictors of psychological well-being of the parents of children with Down syndrome for the group of mothers $(n=75)$

\begin{tabular}{lccc}
\hline Variable & $\beta$ & $t$ & $p$ \\
\hline Perceived stress & -.34 & -3.01 & .004 \\
Perceived social support & .25 & 2.32 & .024 \\
Marital quality & .19 & 1.69 & .096 \\
Ego-resiliency & .17 & 1.62 & .111 \\
\hline Statistics of the model: $R^{2}=.525 ;$ & $F=21.460 ; d f=4 ; p<.001$.
\end{tabular}

Table 4

Predictors of psychological well-being of the parents of children with Down syndrome for the group of fathers $(n=51)$

\begin{tabular}{lrcc}
\hline Variable & $\beta$ & $t$ & $p$ \\
\hline Perceived stress & -.38 & -3.05 & .003 \\
Ego-resiliency & .29 & 2.62 & .012 \\
Perceived social support & .19 & 1.64 & .108 \\
Marital quality & .15 & 1.13 & .263 \\
\hline Statistics of the model: $R^{2}=.446 ;$ & $F=11.048 ; d f=4 ; p<.001$.
\end{tabular}

Perceived stress, ego-resiliency, and relational resources 


\section{DISCUSSION}

The present study assumed that psychological well-being can be an important factor in the process of adaptation of parents of children with Down syndrome and can contribute to maintaining their mental health. Determinants of psychological well-being of these parents were sought. To that end, the Lazarus and Folkman (1987) cognitive theory of stress and coping with concept of resources and positive psy-
Anna Kózka, Hanna Przybyła-Basista chology (Carr, 2011) were combined. Although there are many resources important for parents of children with disabilities (Cunningham, 1996), the authors decided to focus on two types of these resources: social resources (perceived social support and marital quality) and psychological resources (ego-resiliency). The results of the research confirmed the legitimacy of the choice of these variables as predictors of psychological well-being of parents of children with Down syndrome. Although all independent variables turned out to be the predictors of psychological well-being, the strongest (negative) predictor for the group of all parents was perceived stress. Positive predictors for all parents were: ego-resiliency, social support, and marital quality.

The results presented above are compatible with the results of studies related to the role of stress as a risk factor that: burdens the parents, causes difficulties in coping with problems (Cuskelly et al., 2009), and has a negative influence on their physical and mental health (Malhotra et al., 2012). However, the results obtained indicate that positive factors also play an important role in creating psychological well-being. The prime positive predictor was social support from family, friends, and acquaintances. This result is also compatible with the expectations of the authors of the present study because there are a lot of reports in the literature confirming the relationship between support and parents' adaptation and psychical health (e.g. Cuskelly et al., 2009; Liberska \& Rzepa, 2011; Pisula, 2007a; Ylvén et al., 2006). It is worth emphasising that despite many stressors that parents of children with Down syndrome face in everyday life, the influence of stress on parents' psychological well-being can decrease when parents have support from their family and friends. The results presented in this article remain compatible with previous findings by the authors Kózka and Przybyła-Basista, 2016b.

Interesting differences in factors having a positive influence on parents' psychological well-being were revealed between mothers and fathers. In group of mothers, an important factor that determines a positive influence on well-being was perceived social support from family members and friends; in the group of fathers, this factor was ego-resiliency. The meaning of social support for psychological well-being and adaptation process of mothers is compatible with reports by many researchers (e.g. Lam \& Mackenzie, 2002; Hallberg, 2014). Where social support from family and friends is important for mothers, inner resources (ego-resiliency) generate a major base for fathers. In comparison to findings on social support, there is generally a significantly smaller amount of research on the meaning of ego-resiliency for maintaining psychological well-being (e.g. Kózka \& Przybyła-Basista, 2016a). Nevertheless, these findings are interesting and promising, especially when the process of adaptation to the role of caregiver of a child with disability is taken into consideration. Such a personality trait like ego-resiliency can be very useful in developing stress-coping strategies and easing a flexible adjustment to new conditions and demands (Dolińska-Zygmunt \& Włodarczyk, 2011). This research domain is worth investigating further.

The results obtained in the presented study seem to be valuable, although generalisations are not legitimate, mainly due to the size of the sample, especially of the group of the fathers. Further studies should be done with the use of larger samples. It should also be remembered that the values of $\beta$ coefficients suggest that they do not have high predictive ability of the dependent variable. Therefore, the obtained results should be interpreted with caution, and limitations of this research should be taken into consideration.

Although the study conducted is of cross-sectional and not longitudinal nature, the time factor should be counted in further research because it can play an important role in the process of assessing changes to psychological well-being. What is more, apart from perceived social support, received social support should also be researched - especially the support received from the spouse in an intimate relationship. More often, the context of a stressful situation is taken into consideration in current research projects. In the present study, a measure of perceived stress was used; in this way, the character of the stressful situation was not investigated. In further research, the authors of the study plan to use a questionnaire that would be more specific and designed to measure parental stress.

\section{CONCLUSIONS}

The results indicated factors that have a significant influence on parental well-being and thereby are negative (perceived stress) or positive (perceived social support for mothers, ego-resiliency for fathers) to the well-being and mental health of parents of children with Down syndrome, and - indirectly - also for the adaptation process of these parents. Particularly interesting are the differences between mothers and fathers in factors that positively influence their well-being. Relational resources (especially so- 
cial support from family and friends) are important for mothers, whereas inner psychological resources (ego-resiliency) are crucial in the case of fathers; the topic requires further research.

In conclusion, it should be underlined that mothers and fathers differ not only in the aspect of factors contributing to their stress, but also in the factors that have an influence on the process of their adaptation to the role of parents of a child with disability, and maintaining psychological well-being (Neely-Barnes et al., 2008). These findings are valuable in planning effective psychological forms of support for these parents, as well as in designing psycho-educational programmes for parents of children with Down syndrome.

\section{References}

Bailey, D. B., Jr, Blasco, P. M., \& Simeonsson, R. J. (1992). Needs expressed by mothers and fathers of young children with disabilities. American Journal of Mental Retardation, 97, 1-10.

Barnett, D., Clements, M., Kaplan-Estrin, M., \& Fialka, J. (2003). Building new dreams: Supporting parents' adaptation to their child with special needs. Infants and Young Children, 16, 184-200.

Baucom, D. H., Shoham, V., Mueser, K.T., Daiuto, A. D., \& Stickle, T. R. (1998). Empirically supported couple and family interventions for marital distress and adult mental health problems. Journal of Consulting and Clinical Psychology, 66, 53-88.

Block, J. L., \& Kremen, A. M. (1996). IQ and ego-resiliency: Conceptual and empirical connections and separateness. Journal of Personality and Social Psychology, 40, 349-361.

Bobkowicz-Lewartowska, L. (2013). Wybrane uwarunkowania jakości życia rodziców dzieci i mtodzieży $z$ zespotem Downa [Chosen conditions of quality of life of parents of children and youth with Down syndrome]. Warszawa: Difin.

Bower, A., Chant, D., \& Chatwin, S. (1998). Hardiness in families with and without child with Down syndrome. Down Syndrome Research and Practice, 5, 71-77.

Buszman, K., \& Przybyła-Basista, H. (2015). Polska adaptacja Wielowymiarowej Skali Spostrzeganego Wsparcia Społecznego (MSPSS) Gregorego Zimeta i współpracowników - prezentacja właściwości psychometrycznych [Polish adaptation of The Multidimensional Scale of Perceived Social Support by Gregor Zimet et al. - presentation of psychometric properties] (paper submitted for publication).

Carr, A. (2011). Positive psychology: the science of happiness and human strengths. New York: Routledge Taylor and Francis Group.

Cieślak, K. (1989). Polska wersja skali G.B. Spaniera służącej do pomiaru jakości związku małżeńskie- go (DAS) [Polish version of G.B. Spanier's scale of marital quality (DAS)]. Przegląd Psychologiczny, 32, 1041-1049.

Cohen, S., Kamarck, T., \& Mermelstein, R. (1983). A global measure of perceived stress. Journal of Health and Social Behavior, 24, 385-396.

Cunningham, C. (1996). Families of children with Down syndrome. Down Syndrome Research and Practice, 4, 87-95.

Cuskelly, M., Hauser-Cram, P., \& Van Riper, M. (2009). Families of children with Down syndrome: What we know and what we need to know. Down Syndrome Research and Practice, 12, 105-113. doi: 10.3104/reviews/2079

Dąbrowska, A. (2010). Sprawowanie opieki nad dorastającym dzieckiem z zespołem Downa a stres i poczucie koherencji u rodziców [Caring for a growing child with Down syndrome - parents' stress and sense of coherence]. In B. Kaczmarek (ed.), Trudna dorostość osób z zespotem Downa: jak możemy wspomóc? [Difficult adulthood of people with Down syndrome: how can we support it?] (pp. 121-133). Kraków: Oficyna Wydawnicza „Impuls”.

Dolińska-Zygmunt, G., \& Włodarczyk, M. (2011). Ego resiliency and the condition of health. Zdrowie Publiczne, 121, 66-70.

Fidler, D. J., Hodapp, R. M., \& Dykens, E. M. (2000). Stress in families of young children with Down syndrome, Williams syndrome, and Smith-Magenis syndrome. Early Education and Development, 11, 395-406.

Garcia-Tunon, A. (1997). A comparison of the influence of maternal empathy, child's independence skills, and perceived social support, on parenting practices of mothers of preschool children with Down syndrome and mothers of preschool children without disabilities. Humanities and Social Sciences, 58 (6-A), 2159.

Greenberg, J. S, Mailick Seltzer, M., Wyngaarden Krauss M., Chou, R., \& Hong, J. (2004). The effect of quality of the relationship between mothers and adult children with schizophrenia, autism, or Down syndrome on maternal well-being: The mediating role of optimism. American Journal of Orthopsychiatry, 74, 14-25.

Hallberg, U. (2014). Differences in health and well-being of parents of children with disabilities. International Journal of Qualitative Studies on Health and Well-being, 9, 24343.

Hartley, S. L., Mailick Seltzer, M., Head, L., \& Abbeduto, L. (2012). Psychological well-being in fathers of adolescents and young adults with Down syndrome, Fragile X Syndrome, and autism. Family Relations, 61, 327-342.

Hedov, G., Anneren, G., \& Wikblad, K. (2002). Swedish parents of children with Down's syndrome. Parental stress and sense of coherence in relation to employment rate and time spent in child
Perceived stress, ego-resiliency, and relational resources 
care. Scandinavian Journal of Caring Sciences, 16, 424-430.

Hills, P., \& Argyle, M. (2002). The Oxford Happiness Questionnaire: a compact scale for the measurement of psychological well-being. Personality and Individual Differences, 33, 1073-1082.

Hodapp, R., Ly, T., Fidler, D., \& Ricci, L. (2001). Less stress, more rewarding: Parenting children with Down's syndrome. Parenting: Science and Practice, 1, 317-337.

Anna Kózka, Hanna

Przybyła-Basista

Hodapp, R. (2007). Families of persons with Down syndrome: New perspectives, findings, and research and service needs. Mental Retardation and Developmental Disabilities Research Reviews, 13, 279-287.

Joosa, E., \& Berthelsen, D. (2006) Parenting a child with Down syndrome: A phenomenographic study. Journal of Developmental Disabilities, 12, $1-14$.

Juczyński, Z., \& Ogińska-Bulik, N. (2009). Narzędzia pomiaru stresu $i$ radzenia sobie ze stresem [The measures of stress and coping with stress]. Warszawa: Pracownia Testów Psychologicznych.

Kandel, I., \& Merrick, J. (2003). The birth of a child with disability. Coping by Barents and siblings. The Scientific World Journal, 3, 741-750.

Keller, D., \& Honig, A. (2004). Maternal and paternal stress in families with school-aged children with disabilities. American Journal of Orthopsychiatry, 74, 337-348.

Kersh, J., Hedvat, T. T., Hauser-Cram, P., \& Warfield, M. E. (2006). The contribution of marital quality to the well-being of parents of children with developmental disabilities. Journal of Intellectual Disability Research, 50, 883-893.

King, G. A., Zwaigenbaum, L., King, S., Baxter, D., Rosenbaum, P., \& Bates, A. (2005). A qualitative investigation of changes in the belief systems of families of children with autism or Down syndrome. Child: Care, Health and Development, 32, 353-69.

Kołodziej, A., \& Przybyła-Basista, H. (2012). Rola resiliency w pokonywaniu kryzysu rozwodowego: analiza teoretyczna i sposoby pomiaru [The role of resiliency in defeating divorce crisis: theoretical analysis and techniques of measure]. It International Interdisciplinary Conference: Health and Mental Resilience, Krakow, 20-21 October, 2012, Institute of Applied Psychology, Jagiellonian University (polska adaptacja Kwestionariusza J. Blocka i A. M. Kremena Ego-Resiliency Scale) [Polish adaptation of J. Block's and A. M. Kremen's Questionnaire] (unpublished paper).

Kołodziej, A., \& Przybyła-Basista, H. (2013). Oksfordzki Kwestionariusz Szczęścia - polska adaptacja narzędzia do badania dobrostanu: wyniki wstępne [Oxford Happiness Questionnaire - Polish adaptation of well-being measure]. ${ }^{\text {st }}$ Interna- tional Conference on Positive Psychology in Poland (poster). Sopot: SWPS Wydział Zamiejscowy (unpublished paper).

Kózka, A., \& Przybyła-Basista, H. (2016a). The relationships between perceived stress and psychological well-being among mothers and fathers of children with Down syndrome. The New Educational Review, 44, 285-294. doi: 10.15804/ tner.2016.44.2.23

Kózka, A., \& Przybyła-Basista, H. (2016b). Wsparcie społeczne jako czynnik ochronny dla rodziców dzieci z zespołem Downa [Social support as a protection of parents of children with Down syndrome]. Spoteczeństwo i Edukacja, 20, 139-150.

Kulik, M., \& Otrębski, W. (2011). Sytuacja rodziny z dzieckiem niepełnosprawnym w wyniku choroby genetycznej [The situation of parents with disabled child with genetic disorder]. In H. Liberska (ed.), Rodzina z dzieckiem niepetnosprawnym: możliwości i ograniczenia rozwoju [Family with a disabled child: possibilities and limitations of development] (pp. 129-150). Warszawa: Difin.

Lazarus, R. S., \& Folkman, S. (1987). Transactional theory on emotions and coping. European Journal of Personality, 1, 141-169.

Lam, L. W., \& Mackenzie, A. E. (2002). Coping with a child with Down syndrome: the experiences of mothers in Hong Kong. Qualitative Health Research, 12, 223-237.

Laws, G., \& Millward, L. (2001). Predicting parents' satisfaction with the education of their child with Down's syndrome. Educational Research, 43, 209-226.

Liberska, H., \& Rzepa, M. (2011). Rozwój indywidualny rodziców w systemie rodziny z dzieckiem z zespołem Downa [Parents' individual development in system of family of a child with Down syndrome]. In H. Liberska (ed.), Rodzina z dzieckiem niepetnosprawnym: możliwości i ograniczenia rozwoju [Family with disabled child: possibilities and limitations of development] (pp. 197-216). Warszawa: Difin.

Malhotra, S., Khan, W., \& Bhatia, M. S. (2012). Quality of life of parents having children with developmental disabilities. Delhi Psychiatry Journal, 15, 171-176.

Marchal, J., Maurice-Stam, H., Hatzmann, J., von Trotsenburg, A., \& Grootenhuis, M. (2013). Health related quality of life in parents of six to eight year old children with Down syndrome. Research in Developmental Disabilities, 34, 4239-4247.

Mikyong, S., Besser, L., Kucik, J., Chengxing, L., Siffel, C., \& Correa, A. (2009). Prevalence of Down syndrome among children and adolescents in 10 Regions of the United States. Pediatrics, 124, 1565-1571.

Neely-Barnes, S., \& Dia, D. A. (2008). Families of children with disabilities: A review of literature and 
recommendations for interventions. Journal of Early and Intensive Behavior Intervention, 5, 93-107.

Pisula, E. (2007a). Rodzice i rodzeństwo dzieci $z$ zaburzeniami rozwoju [Parents and siblings of children with developmental disorders]. Warszawa: Wydawnictwa Uniwersytetu Warszawskiego.

Pisula, E. (2007b). A comparative study of stress profiles in mothers of children with autism and those of children with Down's syndrome. Journal of Applied Research in Intellectual Disabilities, 20, 274-278.

Przybyła-Basista, H., \& Kózka, A. (2016). Doświadczenie rodzicielstwa przez matki i ojców dzieci z zespołem Downa [Parenthood of mothers and fathers of children with Down syndrome]. In W. Otrębski \& K. Mariańczyk (eds.), Przepis na rehabilitację, tom II Dzieci i młodzież z niepetnosprawnościq [Recipe for rehabilitation, vol. II. Children and youth with disability] (pp. 201-223). Gdańsk: Harmonia (in print).

Ricci, L. A., \& Hodapp, R. M. (2003). Fathers of children with Down's syndrome versus other types of intellectual disability: Perceptions, stress and involvement. Journal of Intellectual Disability Research, 47, 273-284.

Richman, D. M., Belmont, J. M., Myungjin, K., Slavin, C. B., \& Hayner, A. K. (2009). Parenting stress in families of children with Cornelia de Lange syndrome and Down syndrome. Journal of Developmental and Physical Disabilities, 21, 537-553.

Sanders, J., \& Morgan, S. (1997). Family stress and adjustment as perceived by parents of children with autism or Down syndrome: Implications for interventions. Child and Family Behavior Therapy, 19, 15-32.

Schuh, M., Hagner, D., Dillon, A., \& Dixon, B. (2015). The outcomes of family and consumer leadership education: Creating positive change in disability policy and practice. Health Psychology Report, 3, 115-122.

Spanier, G. (1976). Measuring dyadic adjustment: New scales for assessing the quality of marriage and similar dyads. Journal of Marriage and the Family, 38, 15-28.

StatSoft. (2006). Elektroniczny Podręcznik Statystyki PL [Electronic Statistics Textbook]. Kraków. Retrieved from http://www.statsoft.pl/textbook/ stathome.html

Suarez, L. M., \& Baker, B. L. (1997). Child externalizing behavior and parents' stress: the role of social support. Family Relations, 47, 373-381.

Turbiville, V., \& Marquise, J. (2001). Fathers participation in early education programs. Topics in Early Childhood Special Education, 21, 223-231.

Urbano, R. C., \& Hodapp, R. M. (2007). Divorce in families of children with Down syndrome: A population-based study. American Journal on Mental Retardation, 112, 261-274.
West, A. (1998). The piloting of a group for the fathers of children with Down syndrome. Child: Care, Health and Development, 24, 289-294.

Van Riper, M. (2007). Families of children with Down syndrome: responding to change in plans with resilience. Journal of Pediatric Nursing, 22, 116-128.

Van Riper, M. (1999). Maternal perceptions of family-provider relationships and well-being in families of children with Down syndrome. Research in Nursing and Health, 22, 357-368.

Ylvén, R., Björck-Åkesson, E., \& Granlund, M. (2006). Literature review of positive functioning in families with children with a disability. Journal of Policy and Practice in Intellectual Disabilities, 3, 253-270.

Zimet, G., Dahlem, N., Zimet, S. G., \& Harley, G. K. (1988). The mulitidimensional scale of perceived social support. Journal of Personality Assessment, $52,30-41$.
Perceived stress, ego-resiliency, and relational resources 